\title{
The Relevant of Contingency Theory and Stewardship Theory on the Internal Audit Research
}

\author{
Mu’azu Saidu Badara \\ Department of Business Administration, Ahmadu Bello University, Zaria, Nigeria \\ Email address: \\ muazubadara@yahoo.com

\section{To cite this article:} \\ Mu'azu Saidu Badara. The Relevant of Contingency Theory and Stewardship Theory on the Internal Audit Research. Journal of World \\ Economic Research. Vol. 6, No. 2, 2017, pp. 17-22. doi: 10.11648/j.jwer.20170602.11
}

Received: November 27, 2016; Accepted: February 20, 2017; Published: March 10, 2017

\begin{abstract}
Various researches on internal audit has displayed the relevant of internal auditors in objective achievement of an organization, but then up to now, there is no unanimous on factors that best influence the effectiveness of internal audit or framework from the researchers that best predict such internal audit effectiveness, This may perhaps due to inadequate concentrations on sufficient theories in such effectiveness. In line with this, the objective of this paper is to provide theories that may be used in supporting various frameworks on internal audit effectiveness; these theories comprised of contingency theory and stewardship theory, Even though the paper is conceptual, but it then concludes that such effectiveness of internal audit framework can be well explained through contingency theory and stewardship theory.
\end{abstract}

Keywords: Contingency Theory and Stewardship Theory, Internal Audit Effectiveness

\section{Introduction}

Nowadays, researchers from the accounting perspective are given more concerned to the internal audit research (Badara, 2015); this was due the relevant of internal audit in saving management of an organization in every aspect of their operations. Internal audit function has become a very essential function within various organizations in the world. Internal audit effectiveness has not yet been widely studied in auditing literature. That is why; some researchers are still recommending the need for more research to be conducted on internal audit effectiveness predominantly in developing countries (e.g. Al-Twaijry, Brierley \& Gwilliam, 2003; Badara \& Saidin, 2013; Badara \& Saidin, 2014; Badara, 2015; Endaya \& Hanefah, 2013; Mihret \& Yismaw, 2007; Arena \& Azzone, 2007 and 2009; Yee, James \& Leung, 2008; Ahmad, Othman, Othman \& Jusoff, 2009), whereas such internal auditing might play an important role especially with regard to fraud detection and prevention.

Previous studies have make used of various approaches to explore the internal audit effectiveness. Take for instance, (Al-Twaijry et al., 2003) adopted International Standards for Professional Practice of Internal Auditing (ISPPIA) as a guideline toward determining the internal audit effectiveness while others like (Badara \& Saidin, 2013;
Endaya \& Hanefah, 2013; Mihret \& Yismaw, 2007; Arena \& Azzone, 2009; Ahmad et al., 2009) developed their own models to examine the internal audit effectiveness. In this vein, literature shows that different measures and constructs have been employed in determining the internal audit effectiveness by different researchers (Arena \& Azzone, 2009; Badara, 2015) but then, until now, there is no best unanimous framework that described such internal audit effectiveness, even Badara and Saidin, (2013) noted that such effectiveness can be examine through different variables. This indicates the need for more research on internal audit effectiveness.

The relevant of various theories have not been considered by various researches on internal audit effectiveness. Therefore, this paper suggests the combinations of theories which could of help in developing a theoretical framework of internal audit effectiveness and extend the internal audit research that includes: contingency theory and stewardship theory.

\section{Literature Review}

This section explains the relevant of contingency theory and stewardship theory in relating to internal audit research. 


\subsection{Contingency Theory}

Contingency theory is an established theory in organizational research, due to the fact that the theory is deep-rooted in various concepts of organizational literature (Sauser, Reilly \& Shenhar, 2009; Donaldson, 2001). Meanwhile, for the past three decades, attention has been given to the contingency theory in previous studies, but then, it keep considering in the recent time (Ayman, Chemers \& Fiedler, 1995; Badara \& Saidin, 2013). Despite the fact that, those previous researchers in the area of contingency theory mainly concentrated on the effect of uncertainty on organizational structure (Chenhall, 2003; Drazin \& Van de Ven, 1985; Reid \& Smith, 2000).

Theoretically, it is generally accepted that optimal structure of an organization is contingent upon different factors such as the nature of organizational work, organizational technology and market conditions (Nasrallah \& Qawasmeh, 2009). This is in line with the finding of Drazin and Van de Ven (1985) which suggested that organizational performance can be well explained through contingency theory. This shows the historical important of contingency theory.

The word "contingency" means something is only true under specified conditions (Chenhall, 2003). Contingency has also refers to the situation that the effects of one variable on another variable depend on third variables (Donaldson, 2001). Contingency theory is a behavioral theory developed by Woodward (1958) which posited that there is no best way to manage. In line with this, Haldma and Laats (2002) and Reid and Smith (2000) also pointed out that there is no perfect way to provide a good management accounting system but rather depend upon some contingencies to dictate the best option of management accounting system in each particular condition. In this regard, this research provided that internal audit effectiveness can be best explains through contingency theory.

Though, Schoonhoven (1981) criticized the theory by identifying five problems of the theory among which is lack of clarity because the theory depends on few assumptions. Likewise, Drazin and Van de Ven (1985) realized that contingency theory lack the ability to settle theoretical and empirical difficulties. Despite the above criticism, Sauser et al., (2009) confirmed that the contingency theory has the capability that goes beyond traditional achievement because the theory has essential roles in project management success and prevent it failures. This shows the strength of contingency theory even in the aspect of success in project management.

A number of researches have been conducted using contingency theory among which for example are, Fry and Slocum (1984) examined the contingency effect of technology and structure on work group effectiveness and the result revealed negative relationship. Likewise Ayman et al., (1995) and Fiedler and Mahar (1979) used the contingency theory in predicting that effectiveness of a leader is contingent upon his motivational orientation and situational controls. While in the aspect of religion perspective, contingency theory was also been examined by Kriger and Seng (2005) in which they provided that effectiveness of leadership can also be contingent upon the inner value of the leaders and their respective religions (that is; Islam, Buddhism, Christianity, Hinduism and Judaism) that form the five main religions of the world.

Research conducted by Jayaram, Xu and Nicolae (2011) measured the contingency effects of firm size and clock speed whether they can moderate the effectiveness of the relationship between customer and supplier coordination on performance in China. Result of the study revealed significant relationship between customer and supplier coordination on performance but firm size and clock speed does not moderate such relationship. Contingency model is a method which provides a way for leadership performance improvement because it stated that such performance is contingent on personality and the control situation of the leader (Ayman et al., 1995; Fiedler \& Mahar, 1979). Despite the important of contingency theory on the prediction of a relationship, only few study conducted on the effect of such theory on internal audit issues.

The Contingency Approach to Internal Audit Effectiveness

Contingency theory recently has become predominant theory that received larger researcher's concentration in the field of accounting and auditing (Abushaiba \& Zainuddin, 2012; Badara, 2015; Badara \& Saidin, 2014; Ninlaphay \& Ngamtampong, 2013; Reid \& Smith, 2000; Sudsomboon \& Ussahawanitchakit, 2009; Valanciene \& Gimzauskiene, 2009). Despite the fact that, application of theory can resulted to different effect, the effectiveness of a theory may equally be depend upon the proposed area (Drazin \& Van de Ven, 1985; Chenhall, 2003). Additionally, the relevant of any given factor should be contingent upon other factors (Krishnamoorthy, 2002). This is because it does depend on one's interpretation of the theory and such theory possessed the ability in producing precise hypothesis and consistent functions (Schoonhoven, 1981). Likewise, such theory can also be applicable in the context of public sectors settings (Wood, 2009).

Contingency theory is usually applicable in the context of effectiveness achievement. Several researches have used contingency theory in attainment of effectiveness at organizational level (Haldma \& Laats, 2002; Kim \& Umanath, 1993; Kepes, Delery \& Gupta, 2009; Morton \& $\mathrm{Hu}, 2008$; Nicolaou, 2000). For example, Nicolaou (2000) used contingency theory to determine the effectiveness of accounting information system. Finally found that the effectiveness of such system is depend upon three contingent variables that is, organizational formalization, interdependence of information among functional areas in the organization and interdependenceof information sharing with other organizations. Similarly, effectiveness of design accounting systems depends upon its ability to adapt changes from both in external and internal factors (Haldma \& Laats, 2002).

Also, Kim and Umanath (1993) revealed that perceived 
effectiveness is contingent upon the moderation of task on both control structure and decision-making structure. Additionally, the result finding of Kepes et al., (2009) revealed that effectiveness of organization is contingent upon their effective pay range. In the same vein, contingency theory suggested that, the effectiveness of an organization is contingent upon the various elements of sub-systems in which performance measurement is among such sub-system (Haldma \& Laats, 2002; Gimzauskiene \& Kloviene, 2011 Morton \& Hu, 2008). Therefore, going by the above studies, they have displayed the effect of contingency theory in relation to effectiveness achievement. In this regard, since the focused of this study is on the achievement of effectiveness in the area of internal audit. Then the study used contingency theory in predicting that internal audit effectiveness is contingent upon various suitable variables.

Furthermore, research has proven some of the variables in contingency theory research. For instance, Woods (2009) carried out a case study research on the contingency theory perspective on risk management at local government in the UK. The research revealed the contingency effect of risk management upon these variables that include; strategy and technology, external environment and organizational size. In addition, Gordon, Loeb and Tseng (2009) revealed a positive significant contingency effect for the relationship between enterprise risk management and firms performance upon these variables; competition in industry, firm complexity, environmental uncertainty, size of the firm and monitoring by board of directors. Similarly, in the aspect of internal control system effectiveness, Jokipii (2010) used contingency theory to discover the effectiveness of internal control system via considering the following contingent variables; size of the firm, perceived environmental uncertainty, organizational structure and strategy with a mediating variables of internal control structure that comprised the entire five component of internal control system in determining the internal control effectiveness. The study showed significant contingent relationship between the variables except size and organizational structure.

Likewise, the finding of Krishnamoorthy (2008) revealed the contingent effect of audit committee on the relationship between internal auditors and external auditors. However, Sudsomboon and Ussahawanitchakit (2009) used contingency theory in the area concerning audit success, which at the end concluded that, such success is contingent upon these variables; stakeholder force, professional regulation, audit reputation, audit quality and professional competitive. This shows the importance of contingency theory in the auditing perspective. In addition, the study of Endaya and Hanefah (2013) revealed that, the relationship between characteristics of internal auditors and internal audit department performance on internal audit effectiveness is contingent upon organization members' support. Badara (2015) has displayed the effect of contingency theory on the empirical evidence of performance measurement of internal audit function on its effectiveness. Contingency theory is interested generally in the form of the relationship and also assumes that consistent relationship is more effective than inconsistent relationship (Fry \& Slocum, 1984). Meanwhile, a contingency theory differs from other theories in the form of their specific propositions, because the theory hypothesize a conditional relationship between two or more independent variables with a dependent variable and subject it to an empirical validation (Drazin \& Van de Ven, 1985).

Equally, contingency theory enables the examination of variables complexity relationship, such as investigating the moderating or mediating effect of variables under study (Heo \& Han, 2003). This is consistent with Sekaran and Bougie (2009) which affirmed that moderating variables is the one which has strong contingent effect on the relationship between independent variables and dependent variable. Similarly, the used of the theory depend upon the contingencies that fit such conditions (Donaldson, 2001), contingent variables can also differ (Wood, 2009). Therefore, considering above discussions, contingency theory can be very relevant theory in explaining internal audit effectiveness research.

\subsection{Stewardship Theory}

In complementing the above theory, stewardship theory of Donaldson and Davis (1991) was found significant in explaining internal audit the research framework. This is because the theory is mainly concerned with identification of situations in which the interests of the principal and the steward are aligned. In fact, Ebimobowei and Binaebi (2013) noted that, auditing exist as result of stewardship concept and stewardship accounting. Adoption of stewardship approaches within the government sectors will bring a number of changes within the sector, because stewardship theory serve as accountability mechanisms for ensuring good monitoring, good audit and reporting in order to assists in objective achievement (Cribb, 2006).

Equally, Ebimobowei and Binaebi (2013) recommended that, auditing enhance appropriate stewardship reporting. Therefore, using this kind of theory within the context of government agencies will lead to the attainment of their respective objective because the stewardship theory have concerned that might lead to organization success. Stewardship theorists put down a model of governance which promotes the ability of employees to contribute toward strategic objectives achievement (Hernandez, 2012). Stewardship theory concerned with the matters that organizations leaders have the obligation of ensuring better achievement of such organization activities than any other selfishness (Donaldson \& Davis, 1991). Therefore, if the organization did well, its staff will also do well thereby investing their energy in their respective organizations success (Davis, Allen \& Hayes, 2010). The same applicable to local government context, if the local government councils does well therefore, their internal auditors will also did well toward the objective achievement of the local government.

Stewardship theory has been considered as other alternative to agency theory; due to the fact that, the theory is more comprehensive and more realistic in viewing 
management actions and motivations than agency theory. This is because agency theory is based on the economic models whereas stewardship theory is based upon the psychological literature and sociological as well (Albrecht, Albrecht \& Albrecht, 2004). Stewardship is been considered as construct that is suitable to shape important employee behaviors (Schepers, Falk, Ruyter, Jong \& Hammerschmidt (2012). Stewardship theory also emphasized that stewardship outcomes can be contingent upon specific organizational structures (Hernandez, 2012). That is why the stewardship theory has also been used for the purpose of explaining relationships amongst various cultures in family businesses; due to the fact that researchers have extensively revealed that stewardship assists toward the greater achievement of family business operations (Davis et al., 2010). Therefore, the theory can also serve as a complementary theory on the above theory in the context of internal audit effectiveness researches.

Stewardship theory may be valuable, particularly for the purpose of understanding the interactions that exist among important employees, their customers, and organization (Hernandez, 2012). Therefore, governance strategythat is based on stewardship principles are more effective when important employees such as internal auditors develop strong relationships with their organization. In this vein, organizations that have helpful stewards and equally has stewardship planning can easily direct their resources toward maximizing firm performance (Davis et al., 2010). Likewise, the top management within the local government can equally ensure the achievement of internal audit effectiveness through their stewardship approach in ensuring the proper functioning of those antecedents and the effective audit committee within the councils. This is because; provisions and utilization of resources within the public sector setting are the stewardship responsibility of the governing bodies of such government organizations (International Federation of Accountants, 2001).

Stewardship theory also affirmed that, each person's within particular relationships chooses how to act, as an agent or steward (Pastoriza \& Arino, 2008). Therefore, the assumptions of human nature under stewardship theory can be easily described as simplistic because it takes the assumption of objective alignment and thereby increasing structuring relationships within an organization. For this theory to be effective in government sector, the sector needs to provide a sophisticated performance measurement system in place in order to ensure goal achievement of the sector (Cribb, 2006).

Stewardship theory argues that managers are trustworthy and therefore, will not engage in an act that will cause misappropriation of corporate resources. The theory also provided that managers are good stewards of their corporation and they work diligently in orders to attain high levels of corporate objectives (Donaldson \& Davis, 1991). Therefore, good steward lead to internal audit effectiveness, by way of improving the local government administration with the aim of ensuring those antecedents so that to enable the achievement of such local internal audit effectiveness. Consistently, with regard to the result finding of Davis et al., (2010), which revealed that employees' commitment and their level of trust in management activities is positively significantly related to stewardship of such organization.

According to stewardship theory, there are certain factors either situational or psychological that make individuals to become either agents or stewards (Pastoriza \& Arino, 2008). Similarly, the stewardship theory equally deals with the situations upon which staff of an organization can act as stewards in order to achieve the organizational objectives than exploiting their selfishness (Donaldson \& Davis, 1991; Davis et al., 2010). Therefore, employees that are stewards' for example internal auditors, give more concentration to the achievement of organizational objective as a whole than their selfishness, because they are committed to their work toward the objective achievement of such organization.

Stewardship theory agreed that individuals within an organization considered themselves as part of the management and therefore, according to the stewardship theory, managers can joint their efforts in order to achieve the organizational goals. This is because stewardship nature of governance enables the compliance of certain policies within the organizations (Albrecht et al., 2004). Stewardship theory accepts that managers are stewards whose responsible is to align their behaviors with the objectives of their principals. In this regards, management within various are responsible for providing all the necessaries that may influence the effectiveness of internal audit. Stewardship governance is being associated with different structural factors such as leadership systems, managerial practices, routines and procedures (Hernandez, 2012).

Employees can become a steward through developing selfregulatory instrument in order to ensure the achievement of customer demand especially by way of good quality service delivery. Because stewardship ensure the alignment of interests, employees additional efforts from self-actualization in order to benefit the customer (Schepers et al., 2012). This shows that internal auditors can also be a steward in assisting the achievement of organizational objective through the influence of various relevant variables. Stewardship governance also has concerned over the rewarding system to employees which might improve their long term effectiveness on objective achievement (Hernandez, 2012).

\section{Conclusion}

This conceptual paper has depicted the important of internal audit research in connection with relevant theories that is contingency theory and stewardship theory. It is very important for internal auditing research to consider these relevant theories in supporting research framework. More research should be conducted in internal audit in connecting to these theories. Future research should look at the effect of internal audit in financial control in the public sector organizations. Future research should consider the audit experience, audit qualification, audit professionals and other 
as a dimension to internal audit toward improving financial control in public sector setting. Other theories should be given consideration in internal audit research so that to have more theories to support internal audit research.

\section{References}

[1] Abushaiba, I. A, \& Zainuddin, Y. (2012). Performance measurement systemdesign, competitivecapability, andperformance consequences - A conceptual like. International Journal ofBusiness and Social Science, 3 (11), 184-193.

[2] Ahmad, H. N., Othman, R., Othman, R. \& Jusoff, K. (2009). The effectiveness of internal audit inMalaysian public sector. Journal of Modern Accounting and Auditing, 5 (9), 53-62.

[3] Al-Twaijry, A. A. M., Brierley, J. A. \& Gwilliam, D. R. (2003). The development of internal audit inSaudi Arabia: An institutional Theory perspective. Critical Perspectives on Accounting, 14 (5), 507-531.

[4] Albrecht, W. S., Albrecht, C. C., \& Albrecht, C. O. (2004). Fraud and corporate executives: Agency, stewardship and Broken Trust. Journal of Forensic Accounting, V, 109-130.

[5] Arena, M. \& Azzone, G. (2007). Internal audit departments: Adoption and characteristics in ItalianCompanies. International Journal of Auditing, 11 (2), 91-114.

[6] Arena, M. \& Azzone, G. (2009). Identifying organizational drivers of internal audit effectiveness. International Journal of Auditing, 13 (1), 43-60.

[7] Ayman, R., Chemers, M. M, \& Fiedler, F. (1995). The contingency model ofleadership effectiveness: Its levels of analysis. Leadership Quarterly, 6 (2), 147-167.

[8] Badara, M. S. (2015). Empirical Evidence of Performance Measurement of Internal Audit Function onits Effectiveness. Academic Journal of Management Science Research, 1 (1), 1- 10.

[9] Badara, M. S., \& Saidin, S. Z. (2013). The journey so far on internal audit effectiveness: A calling forexpansion. International Journal ofAcademic Research in Accounting, Finance andManagement Sciences, 3 (3), 240 -351. DOI: 10.6007/IJARAFMS/v3-i3/225.

[10] Badara, M. S., \& Saidin, S. Z. (2014). Empirical evidence of antecedents of internal audit effectivenessfrom Nigerian perspective. Middle-East Journal of Scientific Research, 19 (4), 460-471. DOI:10.5829/idosi.mejsr.2014.19.4.1783.

[11] Chenhall, R. H. (2003). Management control systems design within its organizational context: Findings from contingencybased research and directions for the future. AccountingOrganizations and Society, 28, 127-168.

[12] Cribb, J. (2006). Agents or Stewards? Contracting with voluntary organizations. Policy Quarterly, 2 (2),11-17.

[13] Davis, J. H., Allen, M. R., \& Hayes, H. D. (2010). Is blood thicker than Water? Astudy ofstewardship perceptions in family business. Entrepreneurship Theoryand Practice, 10931116. DOI: 10.1111/j.1540-6520.2010.00415.x.

[14] Donaldson, L. (2001). The contingency theory of organizations. Thousand Oaks, CA: SagePublications London.
[15] Donaldson, L., \& J. H. Davis. (1991). Stewardship theory or agency theory: CEO governance andshareholder returns. Australian Journal of Management, 16,49-64.

[16] Drazin, R., \& Van de Ven, A. H. (1985). Alternative forms of fit in contingency Theory.Administrative Science Quarterly, 30, 514-539.

[17] Ebimobowei, A., \& Binaebi, B. (2013). An Examination of the effectiveness ofauditing of localgovernment financial reports in Bayelsa State, Nigeria. Current Research Journal of SocialSciences 5 (2) 45-53.

[18] Endaya, K. A., \& Hanefah, M. M. (2013). Internal audit effectiveness: An approach proposition todevelop the theoretical framework. Research Journal of Finance and Accounting. 4 (10), 92-102.

[19] Fiedler, F. E, \& Mahar, L. (1979). A field experiment validating contingency modelleadershiptraining. Journalof Applied Psychology, 64 (3), 247-254.

[20] Fry, L.W., \& Slocum, J. W. (1984). Technology, structure, and workgroup effectiveness: A test of acontingency model. Academy of Management Journal, 27 (2), 221-246.

[21] Gimzauskiene, E., \& Kloviene, L. (2011). The content of performance measurement system accordingto environment of organization. Economics and Management, 16, 60-65.

[22] Gordon, L. A., Loeb, M. P., \& Tseng, C. (2009). Enterprise risk management and firmperformance: Acontingency perspective. J. Account. Public Policy, 28, 301-327.

[23] Haldma, T., \& Laats, K. (2002). Contingencies influencing the managementaccounting practices ofEstonian manufacturing companies. Management AccountingResearch, 13, 379-400. Doi:10.1006/mare.2002.0197.

[24] Hernandez, M. (2012). Toward an understanding of the psychology of stewardship. Academy ofManagement Review, 37 (2), 172-193.

[25] Heo, J., \& Han, I. (2003). Performance measure of information systems (IS) in evolving computingenvironments: An empirical investigation. Information \& Management, 40, 243-256.

[26] International Federation of Accountants (IFAC) (2001). Governance in the public sector: A governingbody perspective. International Public Sector Study. 535 Fifth Avenue, 26th Floor New York, New York 10017. United States of America.

[27] Jayaram, J., Xu, K., \& Nicolae, M. (2011). The direct and contingency effects of supplier coordinationand customer coordination on quality and flexibility performance. International Journal ofProduction Research, 49 (1), 59-85.

[28] Jokipii, A. (2010). Determinants and consequences of internal control in firms: a contingency theorybased analysis. J Manag Gov, 14, 115-144. Doi 10.1007/s10997-009-9085-x.

[29] Kepes, S., Delery, J, \& Gupta, N. (2009). Contingencies in the effects of pay range on organizationaleffectiveness. Personnel Psychology, 62, 497-531.

[30] Kim, K. K., \& Umanath, N. S. (1993). Structure and perceived effectiveness of software developmentsubunits: A task contingency analysis. Journal of Management Information Systems, 9 (3), 157-181. 
[31] Kriger, M., \& Seng, Y. (2005). Leadership with inner meaning: A contingency theory of leadershipbased on the worldviews of five religions. The Leadership Quarterly, 16, 771-806.

[32] Krishnamoorthy, G. (2002). A multistage approach to external auditor's evaluation of the internal auditfunction. Auditing: A Journal of Practice and Theory,21 (1), 95-122.

[33] Krishnamoorthy, G. (2008). The role of internal audit in the financial statement audit: The contingenteffects of Board independence and audit committee effectiveness. 1-29.

[34] Mihret, D. G. \& Yismaw, A. W. (2007). Internal audit effectiveness: An Ethiopian public sector casestudy. Managerial Auditing Journal, 22 (5), 470-484.

[35] Morton, N. A., \& Hu, Q. (2008). Implications of the fit between organizational structure and ERP: Astructural contingency theory perspective. International Journal of Information Management,28, 391-402.

[36] Nasrallah, W. F., \& Qawasmeh, S. J. (2009). Comparing multi-dimensional contingency fit to financialperformance of organizations. European Journal of Operational Research, 194, 911-921.

[37] Nicolaou, A. I. (2000). A contingency model of perceived effectiveness in accounting informationsystems: Organizational coordination and control effects. International Journal of AccountingInformation Systems, 1, 91-105.

[38] Ninlaphay, S., \& Ngamtampong, N. (2013). Internal control effectiveness and stakeholder credibilityperformance: Evidence from corporate governance awarded firms in Thailand. Journal ofInternational Business \& Economics, 13 (3) $173-186$.

[39] Pastoriza, D., \& Arino, M. A. (2008). When agents become stewards: Introducinglearning in thestewardship theory.

[40] Reid, G. C., \& Smith, J. A. (2000). The impact of contingencies on management accounting systemdevelopment. Management Accounting Research, 11, 427-450. Doi:10.1006/mare.2000.0140.

[41] Sauser, B. J., Reilly, R. R., \& Shenhar, A. J. (2009). Why projects fail? How contingency theory canprovidenew insights-A comparative analysis ofNASA's Mars Climate Orbiter loss. International Journal ofProject Management, 27, 665-679.

[42] Sekaran, U, \& Bougie, R (2009). Research method for business: A skill building approach. Fifthedition. A john Wiley and sons, Ltd. United Kingdom.

[43] Schepers, J., Falk, T., Ruyter, K., Jong, A., \& Hammerschmidt, M. (2012). Principles and principals: Docustomer stewardship and agency control compete or complement when shaping frontlineemployee behavior? Journal of Marketing, 1 (76), 1-20.

[44] Schoonhoven, C. B. (1981). Problems with contingency theory: Testing assumptions hidden within theLanguage of Contingency "Theory. Administrative ScienceQuarterly, 26, 351-377.

[45] Sudsomboon, S., \& Ussahawanitchakit, P. (2009). Professional audit competencies: the effects OnThai's CPAS audit quality, reputation, and success. Review of Business Research, 9 (3), 66-85.

[46] Valanciene, L., \& Gimzauskiene, E. (2009). Dimensions of performance measurement systeminchangesresearch. Engineering Economics (4), 41-48.

[47] Wood, M. (2009). A contingency theory perspective on the risk management control system withinBirmingham City Council. Management Accounting Research, 20, 69-81.

[48] Yee, C. S. L., Sujan, A., James, K. \& Leung, J. K. S. (2008). Perceptions of Singaporeaninternal auditcustomers regarding the role and effectiveness of internal audit. Asian Journal of Businessand Accounting, 1 (2), 147-174. 